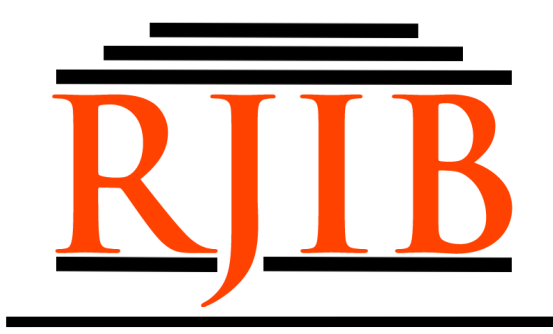

RETORIKA: Jurnal Ilmu Bahasa

Vol. 6, No. 1 April 2020, Page 85-90

\title{
Improvement of English Grammar Understanding Using ERWRT For STMIK STIKOM Indonesia's Students
}

\begin{abstract}
Maria Osmunda Eawea Monny and Evelyn Angelita Pinondang Manurung
STMIK STIKOM Indonesia

maria.monny@stiki-indonesia.ac.id
\end{abstract}

\begin{tabular}{|l}
\hline Received: 08/01/2020 \\
How to cite (in APA style): \\
Monny, M. O. E., \& Manurung, E. A. P. (2020). Improvement of English Grammar Understanding Using ERWRT For \\
$\begin{array}{l}\text { STMIK STIKOM Indonesia's Students. RETORIKA: Jurnal Ilmu Bahasa, 6(1), 85-90. doi: https:// } \\
\text { doi.org/10.22225/jr.6.1.1528.85-90 }\end{array}$ \\
\hline
\end{tabular}

\begin{abstract}
This study aims to improve English grammar understanding using ERWRT for STMIK STIKOM Indonesia's students. The approach in this research is action research using Classroom Action research (CAR). The data are collected by using observation, interview and literary research. The results of this study showed that the implementation of ERWRT has improved students' level of understanding on English grammar that can be seen through pre-implementation, Middle Test (Cycle I) and Final Test (Cycle II). The results of preimplementation show that out of 38 students, there were 28 students did not get the lowest score 55 as the passing score of the college. Middle Test (Cycle I) tested 6 topics those are (1) subject pronouns; (2) preposition of place; (3) simple present tense; (4) agreement of subject and verb; (5) agreement of numbers and nouns dan (6) simple past tense. The results of the test show that out of 36 students only 18 students get the score above 55. Final Test (Cycle II) there is 15 numbers tested with 6 previous topics and 6 new topics; those are (1) article; (2) object pronouns; (3) time division (AM/PM); (4) telling time and (5) modal verbs. The results of Cycle II show that 35 students can score above 55. In conclusion, ERWRT can be applied to improve students' level of understanding on English grammar and writing skills. This test also can be used to analyze grammar error through reading but cannot be used for listening and speaking skills.
\end{abstract}

Keywords: evaluation, improvement, ERWRT

\section{INTRODUCTION}

In learning process, evaluation process has important role in order to encourage students to study hard gradually and at the same time encourage the teachers to improve learning process quality. Besides that, it will help the educational foundation to improve its facility and the quality of students. Responding to the issue, optimizations of evaluation systems of the students has two aspects, first is the evaluation system that gives sufficient information and second is the benefits from the students' evaluation. The main benefit of evaluation is improve learning qualities and automatically will give the impacts to the improvement of education. According to
(Djaali \& Muljono, 2008), there are four functions of test in education, those are 1) as the measurement of students' achievement; 2) to measure students' progress or improvement level after doing the learning process for certain period of time; 3 ) as motivator in learning process and 4) as a tool for improvement of learning quality because test is done to improve learning quality.

Based on the data collection through learning process in the classroom from the previous English Language I class, students were able to answer the questions correctly in multiple choice tests during their examination but they cannot give the reason why the answers are correct. This fact figures out that they just answered by doing speculation. In 
order to know if they understand the topics correctly; there must be additional requirements from the test. The additional requirements are after choosing the correct option, they must write the correct answer and in then write the reasons grammatically and correctly. In this way, the lecturer can figure out whether the students understand the topics well. According to (Dykes, 2007), the meaning of very simple grammar and probably the correct one is language that talks about language. Error recognition is one of multiple choices by defining the wrong answer. According to (Burn, 1999) error is different from mistake. Error is caused by students' proficiency. This means, the students do not understand yet the linguistics proficiency while mistake is caused by students' performance. In other words, students forgot to apply certain voice, words or series of words, intonation or sentences. Error recognition with reason test is a design of test that was developed by the researcher from error recognition test by adding two columns; those are correct answer as part of multiple choice and reasons column as an essay test for writing. The additional columns (correct answer and reasons) enable the researcher to measure students' level of understanding on English grammar. At the right answer column, the research is able to know that the answers given by the students not based on their speculations. While for the reasons column, the students can write the reasons of their answers. Reason column does not only measure their level of understanding but also students writing skills.

According to (Yule, 2006) there are three approaches in language teaching, those are 1) The grammar translation method which is the traditional method in teaching foreign language using vocabularies and grammar of students, encourage the students to memorize and written language is more important than oral language; 2) The audio-lingual method which emphasizes on written language and 3) Communicative approach which is improvement of second language learning as the reaction of 'practice patterns' and the reassurance that learning certain language's grammar consciously will bring the result on skill to use the language. The implementation of English Language in Indonesia as foreign language has put it as a mandatory subject. However it is only for its academics purposes only. The limitation of this implementation has made the students has lack of initiative and eagerness to learn English seriously because the aim is only the grades. Recently, this has become the obstacles at workplace where English is part of requirements.

Several previous related studies have been conducted by some researcher, such as research by (Burhanuddin, 2015) entitled "Improving The Students' Ability in English Grammar Through "Easy to Learn English Grammar Compact Disc" Computer Software". This study aims at knowing the students' interest in learning English Grammar through Easy to Learn English Grammar Compact Disc (ELEG CD) computer software. The results of this study showed that the students of TKJ (Technique, Computer, and Network) in the SMK Bajiminasa Makassar were increasing in learning English Grammar through Easy to Learn English Grammar Compact Disc computer software. This was proved by the aggregate percentage of the students got from the questionnaires that is from item 1 up to 10 . Based on the findings, the researcher make conclusion that in English grammar through "Easy to Learn English Grammar Compact Disc" computer software could improve the students' ability. Moreover, (Inayati \& Damayanti, 2016) in their research entitled “Improving students' grammar ability (simple past tense) using Johnny Grammar Word Challenge application in junior high school". This study aims to analyze the effectiveness of Johnny Grammar Word Challenge in improving students' grammar ability especially simple past tense in Junior High School level. The result shows that the use of Johnny Grammar Word Challenge could improve the student's grammar ability. From affective aspect, the students can use their mobile phone effectively. Psychomotor aspect, they enjoy giving positive response toward the implementation of the application. Then, from cognitive aspect, they have been able to determine the appropriate verb which is used in a past tense sentence. Johnny Grammar Word Challenge is suitable to be implemented to improve student's grammar ability especially simple past tense. Thus, the researchers suggest teachers to use it as a variation in teaching English. (Agustini, Wardhani, \& Amalina, 2018) carried out the similar study entitled "Improving Students' Grammar Skill Through Student Centered Learning at ITATS". The aim of this research was to give proposal of English learning to improve students' grammar ability. The result of this research was $87 \%$ of students got to increase score for post-test and $30 \%$ of students passed the score. Thus, students' center learning method was effective to increase students' grammar ability. 
Based on the background and the latest related studies above, the purpose of this study is to improve English grammar understanding using ERWRT for STMIK STIKOM Indonesia's students.

\section{METHOD}

The approach in this research is action research using Classroom Action research (CAR). CAR is a research activity that is done to solve the problem in learning process based on cycle. In every cycle, there are four levels those are planning; acting; observing and reflection (Arikunto, 2006). These four levels are done as a repeated cycle based on research needs. This cycle will be stopped if the aims of the research are achieved. Data collecting technique of this research is done in three ways; those are observation, interview and literary research. The observation is done through Pre-Implementation, Cycle I (Mid Test) and Cycle II ( Final Test), interview is doen through quesioner and literary research through Lesson Plan and other teaching administations. The data gathered based on the interview through questioner filled by the students. Questioner is an instrument that contains questions about the difficulties in learning English.

\section{RESULTS AND DISCUSSION}

Observation of pre-action was conducted on Tuesday, 10 September 2019 with the purpose to know the participation and English grammar understanding of Class Y. There were 38 students for the subject English Language I before the implementation of Error Recognition with Reason Test (ERWRT). In preimplementation, test applied was Error Recognition that is mostly used on Test of English as Foreign Language (TOEFL). Error recognition test is used by the research in order to know which topics that really understood well by the students before the lesson started. The topics for the test were: (1) nouns (singular/plural); (2) articles; (3) preposition of time; (4) subject pronoun; (5) prepositions of place; (6) simple present tense; (7) object pronouns, (8) adjective; (9) simple past tense; and (10) simple future tense.

The results shows that out of 38 students only 10 students passed the passing score 55 . This shows low level of English grammar understanding that must be improved through learning process and the implementation of ERWRT. In order to know what are the factors that influenced students' level of understanding on English grammar, students are given the questioner with open questions. Based on 36 questioners of the students, there are 5 factors ( 2 internal and 3 external) that influenced the students' level of understanding. The three factors are (1) lack of activities to speak directly with native speakers lack of time to review the lessons given by lecturers; (2) lack of mastery of English vocabulary and easily get confuse due to the changes of verbs in tenses and (3) lack of confidence to do the communication though knowing the importance of English for the future. There are 2 external factors; those are lack of regulations of speaking English activity every Monday and lack of materials provided from college at the library.

From the external and internal factors can be list down as follows: lack of mastery of English vocabulary and easily get confuse due to the changes of verbs in tenses (55\%), lack of activities to speak directly with native speakers lack of time to review the lessons given by lecturers $(18 \%)$, lack of confidence to do the communication though knowing the importance of English for the future (11\%), lack of regulations of speaking English activity every Monday (10\%), and lack of materials provided from college at the library $(6 \%)$. Besides that, the students can do the following in order to improve the English grammar understanding: (1) doing the practice with native speakers; (2) use the time wisely to do review of the lessons; (3) spend time more on reading English dictionaries and books in English; (4) practice English directly at workplace especially in computers and (5) must understand English sentence patterns. While for the implementation of ERWRT, the students realize that it really helps them because they do not just answer it but they must understand it well. It also helps them to memorize the sentence patterns.

Cycle I was done on Middle Test on Tuesday, 29 October 2019, attended by 36 students using ERWRT. The result shows that the level of students' understanding increases. The increases are shown through column wrong answer (options), column correct answers and column reasons. For column wrong answer and right answer is only 1 point if correct and 0 if wrong. For column reason: 3 points for correct answer, 2 points for correct answer but wrong grammar; 1 point for wrong answer and 0 for no answer. Total points for each number are 5 . The topics for the test were (1) subject pronouns (No. 1); (2) preposition of 
place (No. 2); (3) simple present tense (No. 3, 4 and 6); (4) agreement of subject and verb (No. 5,7 and 10 ; (5) agreement of numbers and nouns (No. 8) and (6) simple past tense (No. 9).

The results of Cycle I or Middle Test are as follows:

1. Subject pronouns: 28 students answered correct option, 20 students wrote correct answers and 10 students wrote correct reasons, 8 students wrote correct reason wrong grammar, 10 students wrote wrong answer and 8 students did not write the reasons.

2. Preposition of place: 27 students answered correct option, 23 students wrote correct answers and 20 students wrote correct reasons, 5 students wrote correct reason wrong grammar, 5 students wrote wrong answer and 6 students did not write the reasons.

3. Simple present tense: 20 students answered correct option, 17 students wrote correct answers and 16 students wrote correct reasons, 10 students wrote correct reason wrong grammar, 5 students wrote wrong answer and 5 students did not write the reasons.

4. Agreement of subject and verb: 16 students answered correct option, 10 students wrote correct answers and 16 students wrote correct reasons, 10 students wrote correct reason wrong grammar, 5 students wrote wrong answer and 5 students did not write the reasons.

5. Agreement of numbers and nouns: 13 students answered correct option, 10 students wrote correct answers and 10 students wrote correct reasons, 10 students wrote correct reason wrong grammar, 6 students wrote wrong answer and 10 students did not write the reasons.

6. Simple past tense: 18 students answered correct option, 15 students wrote correct answers and 9 students wrote correct reasons, 12 students wrote correct reason wrong grammar, 10 students wrote wrong answer and 5 students did not write the reasons.

The results of Cycle I (Middle test) is shown in graph:

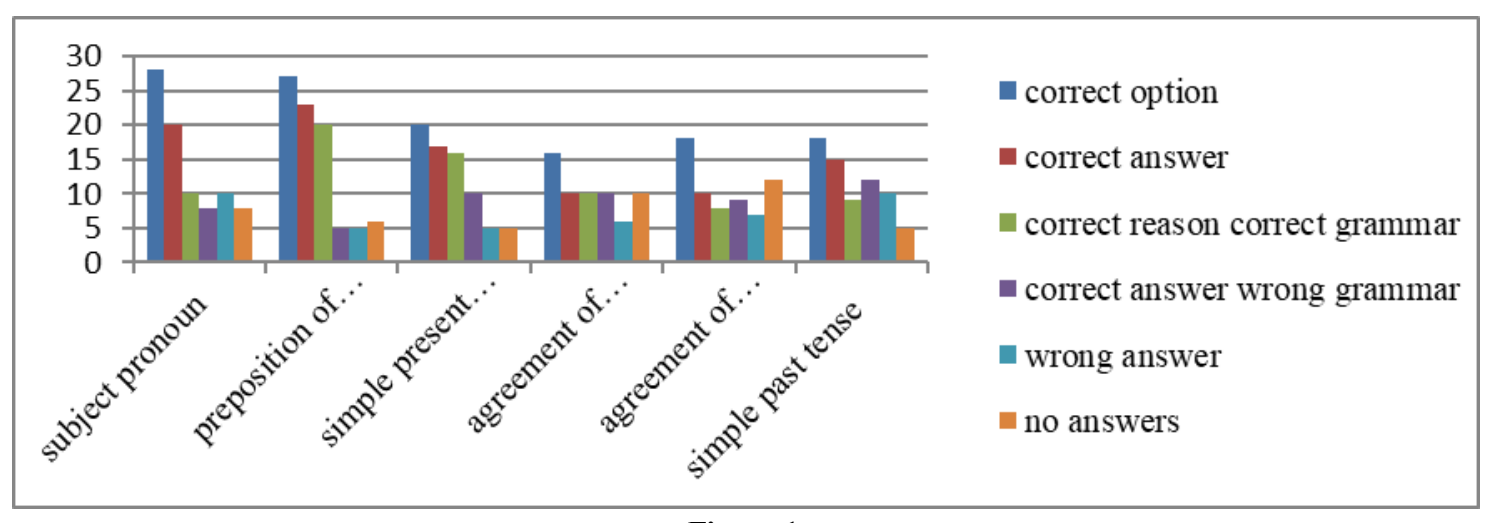

Figure 1

The Results of Cycle I

The results of Cycle I (Middle Test) shows that correct option and correct answer the students tends to do the speculations that can be seen in their reasons. The results shows that out of 38 students only 18 students can pass the passing scores 55 . In order to improve students' level of understanding, the learning process is conducted and Cycle II needed to be done in Final Test.

Cycle II was done on Final Test on Tuesday, 7 January 2020, attended by 35 students using ERWRT. The result shows that the level of students' understanding increases. There were 15 numbers of test consist of 6 previous topics and 5 new topics. The previous topics were given in order to measure students' level of understanding. 5 new topics were (1) article; (2) object pronouns; (3) time division (AM/PM); (4) telling time and (5) modal verbs.

For the 6 previous topics the students can answered the questions correctly although with very simple grammar in their reasons column.

1. Subject pronouns: 30 students answered correct option, 28 students wrote correct answers and 28 students wrote correct reasons, 3 students wrote correct reason wrong grammar, 2 students wrote wrong answer and 2 students did not write the reasons.

2. Preposition of place: 29 students answered correct option, 26 students wrote correct 
answers and 30 students wrote correct reasons, 1 student wrote correct reason wrong grammar, 1 student wrote wrong answer and 3 students did not write the reasons.

3. Simple present tense: 31 students answered correct option, 29 students wrote correct answers and 28 students wrote correct reasons, 1 student wrote correct reason wrong grammar, 2 students wrote wrong answer and 4 students did not write the reasons.

4. Agreement of subject and verb: 28 students answered correct option, 25 students wrote correct answers and 27 students wrote correct reasons, 2 students wrote correct reason wrong grammar, 3 students wrote wrong answer and 3 students did not write the reasons.

5. Agreement of numbers and nouns: 33 students answered correct option, 30 students wrote correct answers and 27 students wrote correct reasons, 2 students wrote correct reason wrong grammar, 2 students wrote wrong answer and 4 students did not write the reasons.

6. Simple past tense: 30 students answered correct option, 27 students wrote correct answers and 29 students wrote correct reasons, 2 students wrote correct reason wrong grammar, 2 students wrote wrong answer and 4 students did not write the reasons.

For 5 new topics: (1) article; (2) object pronouns; (3) time division; (4) telling time and
(5) modal verbs.

1. Article: 28 students answered correct option, 26 students wrote correct answers and 20 students wrote correct reasons, 7 students wrote correct reason wrong grammar, 5 students wrote wrong answer and 3 students did not write the reasons.

2. Object pronouns: 27 students answered correct option, 24 students wrote correct answers and 26 students wrote correct reasons, 3 students wrote correct reason wrong grammar, 3 students wrote wrong answer and 3 students did not write the reasons.

3. Time division: 30 students answered correct option, 25 students wrote correct answers and 30 students wrote correct reasons, 2 students wrote correct reason wrong grammar, 1 student wrote wrong answer and 2 students did not write the reasons.

4. Telling time: 29 students answered correct option, 24 students wrote correct answers and 28 students wrote correct reasons, 2 students wrote correct reason wrong grammar, 2 students wrote wrong answer and 3 students did not write the reasons.

5. Modal verbs: 28 students answered correct option, 23 students wrote correct answers and 25 students wrote correct reasons, 5 students wrote correct reason wrong grammar, 3 students wrote wrong answer and 2 students did not write the reasons.

The result of Cycle II (Final Test) is shown in graph below:

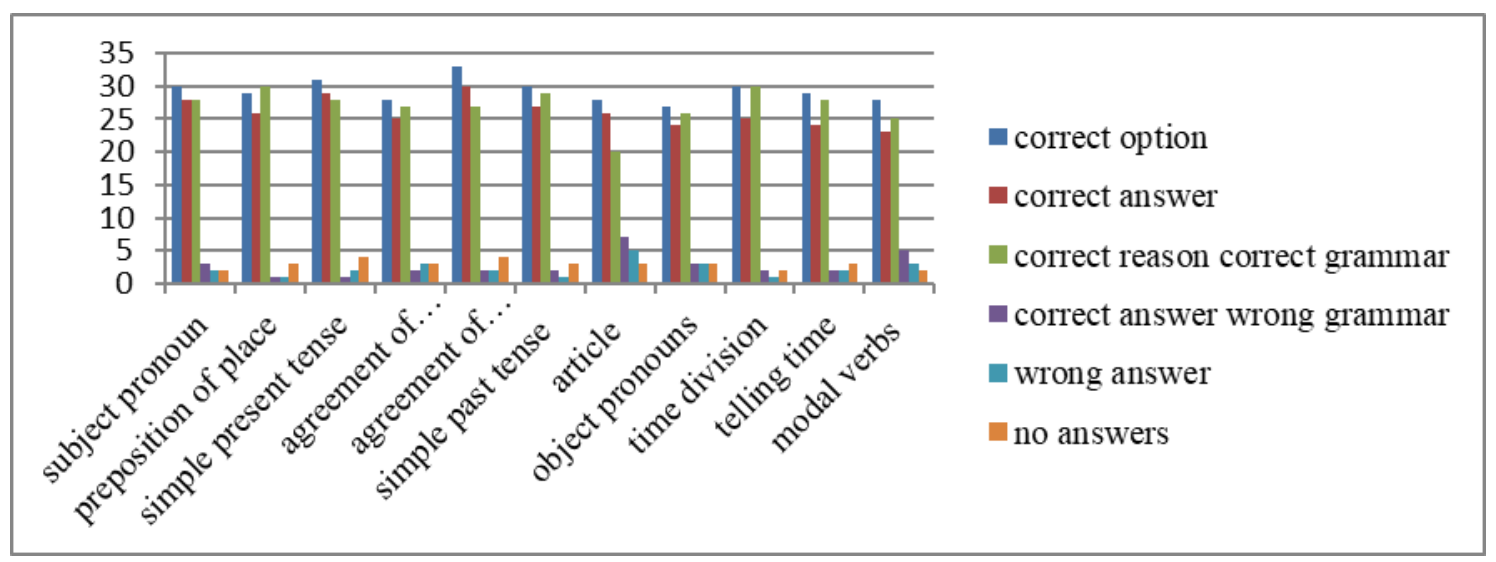

Figure 2

The Results of Cycle II

The results of Cycle II (Final Test) show the progress in correct option and correct answer. For the reason column, the progress can be seen in correct reason correct grammar.
The results show that the students can understand the lessons and got the score above 55. 


\section{CONCLUSIONS}

Based on the purposes and the results obtained from the discussion above, thus it can be drawn the conclusion that there are 5 factors ( 2 internal and 3 external) that influenced the students' level of understanding. lack of mastery of English vocabulary and easily get confuse due to the changes of verbs in tenses $(55 \%)$, lack of activities to speak directly with native speakers lack of time to review the lessons given by lecturers (18\%), lack of confidence to do the communication though knowing the importance of English for the future $(11 \%)$, lack of regulations of speaking English activity every Monday (10\%), and lack of materials provided from college at the library $(6 \%)$. The implementation of ERWRT has improved students' level of understanding on English grammar that can be seen through pre-implementation, Middle Test (Cycle I) and Final Test (Cycle II). The results of preimplementation show that out of 38 students, there were 28 students did not get the lowest score 55 as the passing score of the college. Middle Test (Cycle I) tested 6 topics those are (1) subject pronouns; (2) preposition of place; (3) simple present tense; (4) agreement of subject and verb; (5) agreement of numbers and nouns dan (6) simple past tense. The results of the test show that out of 36 students only 18 students get the score above 55. Final Test (Cycle II) there is 15 numbers tested with 6 previous topics and 6 new topics; those are (1) article; (2) object pronouns; (3) time division (AM/PM); (4) telling time and (5) modal verbs. The results of Cycle II show that 35 students can score above 55. This test can be applied to improve students' level of understanding on English grammar and writing skills. This test also can be used to analyze grammar error through reading but cannot be used for listening and speaking skills. The result from the questioner for the implementation of ERWRT for the students are: (1) ERWRT does help the students in order to understand better English grammar because the students must write correct answers with correct grammar based on their options; (2) helping the students with correct dictions for better understanding and (3) students cannot do the speculations because wrong speculations means no points.

\section{REFERENCES}

Agustini, S., Wardhani, N. P., \& Amalina, E. N. (2018). Improving Students' Grammar Skill Through Student Centered Learning at ITATS. English Focus: Journal of English
Language Education, 1(2), 77-85. Retrieved from https://doi.org/10.24905/efj.v1i2.32

Arikunto, S. (2006). Prosedur Penelitian Suatu Pendekatan Praktis. Jakarta: Rineka Cipta.

Burhanuddin, W. (2015). Improving the Students' Ability in English Grammar Through " Easy to Learn English Grammar Compact Disc" Computer Software. Jurnal Pendidikan Bahasa Inggris: Exposure, 4(1), 100-117. Retrieved from https://journal.unismuh.ac.id/ index.php/exposure/article/view/922

Burn, A. (1999). Collaborative Action Research for English Language Teacher. Cambridge: Cambridge University Press. Retrieved from https://www.researchgate.net/ publication/245686550_Collaborative_action _research_for_English_teachers

Djaali, \& Muljono, P. (2008). Pengukuran dalam Bidang Pendidikan. Jakarta: Grasindo. Retrieved from https:// librarystikespkj.files.wordpress.com/2017/10 /d08120034-371-dja-p-pengukuran-dalambidang-pendidikan-2008_library-stikespekajangan-2014.pdf

Dykes, B. (2007). Grammar for Everyone, Practical Tools For Learning and Teaching Grammar. Victoria: Australian Council for Educational Research Ltd. Retrieved from https:// search.informit.com.au/

documentSummary; $\mathrm{dn}=755454593439965$;re $\mathrm{s}=$ IELHSS; type $=$ pdf

Inayati, A. M., \& Damayanti, D. (2016). Improving students' grammar ability (simple past tense) using Johnny Grammar Word Challenge application in junior high school. In ICTTE: International Conference on Teacher Training and Education (pp. 876-881). Universitas Sebelas Maret. Retrieved from https://jurnal.uns.ac.id/ictte/article/ view/12378

Yule, G. (2006). The Study of Language. Cambridge: Cambridge University Press. Retrieved from https://fac.ksu.edu.sa/sites/ default/files/ cambridge.the_study_.of_language.4th.editi on.apr_.2010.ebook-elohim.pdf 